\title{
Epidemiology of Shiga toxin-producing Escherichia coli 0157:H7 in Africa in review
}

\author{
Athumani M Lupindua* \\ ${ }^{a}$ Department of Veterinary Medicine and Public Health, College of Veterinary and Biomedical Sciences, Sokoine University of Agriculture, Morogoro, \\ Tanzania \\ *Emails: amsalale@yahoo.com,alupindu@suanet.ac.tz

Shiga toxin-producing Escherichia coli (STEC) 0157:H7 is responsible for intestinal and extra-intestinal disease syndromes in human. Isolation of the pathogen from animals, food, clinical samples and environment has been reported from all continents. A review of STEC 0157:H7 in Africa from a structured literature search of the PubMed electronic database is presented. It describes the epidemiological status of the pathogen on the aspects of source, transmission, pathogenesis, disease syndromes, diagnosis, disease burden and the challenges in treatment and control strategies. About a quarter of African countries have reported isolation of STEC 0157:H7 either from humans, animals, food or the environment. Different methods have been used in detection of the pathogen. Most reported human infections do not show temporal relationships with reports of isolation of the pathogen from other sources such as animals, water or food. Lack of a direct link between isolates from humans and other sources makes it difficult to point out incident specific determinants and direction of transmission. The aim of this review is to give an insight into the features of STEC O157:H7 infection in Africa and draw the attention of various stakeholders to the public health threat of the pathogen for possible interdisciplinary and multi-sectoral joint efforts in the control strategies.

Keywords: Africa, E. coli O157:H7, HUS, Shiga toxin, STEC

\section{Introduction}

Escherichia coli strains that cause diarrhea in humans are either enterotoxigenic $E$. coli (ETEC), enteroaggregative $E$. coli (EAEC), enteropathogenic $E$. coli (EPEC), enteroinvasive $E$. coli (EIEC), diffusely adherent E. coli (DAEC) or verocytotoxigenic $E$. coli (VTEC). ' One of the VTEC stains associated with diarrhea, bloody diarrhea, haemorrhagic colitis and haemolytic uremic syndrome (HUS) is the Shiga toxin-producing Escherichia coli (STEC) O157:H7.2 Once described as a rare serotype causing human infection, ${ }^{3}$ STEC 0157:H7 is now widespread in food products ${ }^{4-6}$ and the environment., ${ }^{7,8}$ This prevalent nature and other biological characteristics, such as low infective dose, ${ }^{7,9-11}$ ability to express different virulence factors, ${ }^{9}$ long survival time in the environment ${ }^{12}$ and the difficulty in treatment, ${ }^{13}$ make STEC 0157:H7 an enteric pathogen of major concern worldwide. This report reviews the epidemiology of the pathogen with focus on (1) distribution, (2) disease manifestation, (3) pathogenicity, (4) isolation and characterization, (5) treatment, (6) disease burden and (7) prone groups. The aim is draw the attention of public health stakeholder to this health problem in Africa so that multidisciplinary joint efforts can be applied in the control strategies.

\section{Methodology}

A search algorithm with terms 'shiga-toxigenic Escherichia coli' OR 'shiga-toxigenic' AND 'Escherichia' AND 'coli' OR 'shigatoxigenic Escherichia coli' OR 'STEC' AND ‘O157' AND 'H7' AND 'Africa' was developed in a PubMed data base on 20 June 2015 to search for articles published in last 10 years. A total of 68 journal articles were initially obtained and 37 of them were selected for the report because they described subjects of interest. A search through the reference list of the selected articles provided additional references about the pathogen in relation to hosts, reservoirs, isolation techniques, virulence, pathogenicity, clinical signs, disease burden, treatment, control and threat to the immunocompromised population. Some references of non-
African context are included in this review to cover general issues for a broader view of the pathogen.

\section{The burden of STEC 0157:H7 infection}

Globally STEC causes 2801000 acute illnesses annually, with an incidence rate of 43.1 cases per 100000 person-years. This burden leads to 3890 cases of HUS and 230 deaths. Among those, a total of 10200 cases of STEC infections occur in Africa with an incidence rate of 1.4 cases per 100000 person-years. STEC 0157:H7 contributes $10 \%$ to this burden. ${ }^{14}$

\section{Reports of STEC 0157:H7 Occurrence in Africa}

Shiga toxin-producing Escherichia coli 0157:H7 isolation has been reported from all zones of Africa (East, Central, South, North and West Africa) from humans, animals, food products and the environment. The first case of human infection was reported back in 1990 in Johannesburg, South Africa. ${ }^{15}$

In central Africa, the pathogen has been isolated in humans with haemorrhagic colitis in Bangui, Central African Republic in 1996, which led to mortalities. ${ }^{13}$ In 1998, STEC 0157:H7 isolation from humans was reported following an outbreak of bloody diarrhoea in Cameroun. ${ }^{16}$

In east Africa, isolation of the pathogen has been reported in Tanzania, Kenya and Ethiopia. A STEC 0157:H7 prevalence of more than $7 \%$ was reported in patients with diarrhoea in Morogoro, Tanzania in $2006 .{ }^{17}$ In 2012, the pathogen was isolated from cattle in the same area with a prevalence of $0.9 \% .{ }^{18}$ In Kenya, STEC 0157:H7 was isolated from a two-year-old boy with haemorrhagic colitis. ${ }^{19}$ Milk and cattle faeces subsequently tested positive for the pathogen in the same country. ${ }^{6}$ STEC O157:H7 has been isolated from beef, mutton and chevon in Ethiopia at a prevalence of $8,2.5$ and $2 \%$, respectively, ${ }^{20}$ as well as goat and sheep faeces $(4.7 \%)$, skin swabs $(8.7 \%)$, carcass before washing $(8.1 \%)$, carcass after washing $(8.7 \%)$ and water samples $(4.2 \%){ }^{21}$ 
Reports on STEC 0157:H7 occurrence are available from Algeria, Morocco, Tunisia and Egypt (north Africa). A study in Algeria reported a prevalence of $7 \%$ from bovine carcasses. ${ }^{5}$ In Morocco, a prevalence of $9.1 \%$ from dairy products and $11.1 \%$ in meat marketed in Rabat have been reported. ${ }^{22}$ STEC 0157:H7 was again isolated in Morocco from raw meat products at a proportion of $9 \% .{ }^{4}$ In 2011, a 1.9\% prevalence from shellfish in Mediterranean coastline of Morocco was reported. ${ }^{23}$ In Tunisia, 3.4\% of isolates from human stool samples were shiga toxin-producing E. coli O157:H7.24 Isolation of the pathogen from different sources has also been documented from Egypt. For instance, a survey in Egypt revealed that a prevalence of $6 \%$ from beef samples, $4 \%$ from chicken samples, $4 \%$ from lamb samples and $6 \%$ from milk samples was obtained in slaughterhouses, supermarkets and farmers' homes. ${ }^{25}$

In west Africa, much of the work reported on STEC 0157:H7 has been from Nigeria. In Lagos, a prevalence of $6 \%$ from patients with diarrhoea has been documented. ${ }^{26}$ In the city of Ibadan, STEC 0157:H7 has been isolated from the faeces of cattle, sheep, goat and pig, and also from beef, chevon (goat) and pork with a prevalence of $5 \% .{ }^{27}$ In Zaria, the strain has been isolated from the diarrheal stool of children under the age of 5 years with a prevalence of $5.4 \%$ and from surface water at a proportion of $2.2 \% .{ }^{28}$ The STEC 0157:H7 isolation in Nigeria provides evidence of occurrence of the pathogen in human, animals, meat and environment (water). A study in the coastal savannah zone of Ghana did not report on the isolation of E. coli O157:H7 in raw milk and milk products, ${ }^{29}$ but this does not guarantee absence of the pathogen. Information on recovery of E. coli O157:H7 from other western African countries, including Mali, Niger, Guinea, Ivory Coast, Togo, Benin, Guinea Bissau, Sierra Leone, Liberia, Mauritania, Cape Verde and Burkina Faso, were not accessed. But given the similarity between environments, there is high chance that this pathogenic E. coli strain exists in these countries. The lack of reports on E. coli $0157: \mathrm{H} 7$ isolation in some African countries may be due to poor diagnostic facilities, especially in rural settings where infections may pass undiagnosed.

The southern African region is comprised of Zambia, Malawi, Mozambique, Zimbabwe, Botswana, Namibia, Swaziland, Lesotho and South Africa. In South Africa, a 10.3\% prevalence of STEC 0157:H7 from vegetable samples in Eastern Cape province was documented. ${ }^{30}$ Meat and meat products from the same location carried the pathogen at a proportion of $2.8 \% .{ }^{31}$ Further studies reported a prevalence of $56.5 \%$ and $43.5 \%$ from stool of confirmed and non-confirmed HIV/AIDS patients, respectively, in the Eastern Cape province. ${ }^{32}$ The STEC 0157:H7 isolates from meat products $(7.8 \%)$, water $(8.6 \%)$, vegetables $(10.3 \%)$, confirmed HIV/AIDS patients (56.5\%) and non-confirmed HIV/ AIDS patients (43.5\%) were genetically related; ${ }^{30}$ and, hence, provided evidence on the possible transfer of the pathogens between different study components. In the neighbouring country of Botswana, the prevalence of STEC 0157:H7 in meat cubes, minced meat and fresh sausages in Gaborone were reported to be $5.22,3.76$ and $2.26 \%$, respectively. ${ }^{33}$ These findings from beef-product outlets put consumers at risk of infection. Home cooked food samples (maize flour porridge, fish, vegetables and beans) investigated for pathogenic bacteria, were found to be contaminated with STEC 0157:H7 at a proportion of $8 \%$ in Lungwena, Malawi. ${ }^{34}$ In Mozambique, the pathogen was reported to be one of the causes of diarrhoea in children at a proportion of $1.9 \%{ }^{35}$ STEC 0157:H7 was reported to also cause dysentery in HIV patients in Zimbabwe at a prevalence of $8 \% .^{36}$
Therefore, reports on isolation of pathogenic E. coli O157:H7 from all regions of the African continent (east, west, south, north and central) show that the pathogen is found throughout Africa. A total of 15 countries have reported recovery of pathogenic $E$. coli 0157:H7 either from humans, animals, food products or the environment. Out of 30 reviewed cases, 10 (33.3\%) come from human patients and the remaining 20 isolations (66.7\%) belong to food stuffs, ${ }^{8}$ cattle, ${ }^{5}$ water ${ }^{3}$ and others ( 2 sheep and goats, 1 vegetable and 1 shell fish) (Table 1 ).

\section{Transmission of STEC 0157:H7}

STEC 0157:H7 is an enteric pathogen that is transmitted to humans through ingestion of contaminated food, or hands to mouth. ${ }^{7,37}$ Person-to-person contact can lead to transmission of the pathogen through the oral-faecal route. ${ }^{9}$ The infectious dose that has caused disease symptoms in humans has been reported to be as low as 4 to 24 organisms. ${ }^{7,11}$ Ruminants are said to be reservoirs, whereby cattle are regarded as principal sources of infections. ${ }^{6,38-42}$ However other ruminant species, such as goats, sheep, ${ }^{21,27}$ and buffaloes, ${ }^{43}$ serve as a source of the pathogen, with the exception for camels. ${ }^{44}$ Non-ruminant animals such as pigs $^{27,38,39}$ and pigeons ${ }^{45}$ are also reported to carry this strain of pathogenic E. coli. Fish in contaminated water have been reported to harbour STEC 0157:H7. ${ }^{46} \mathrm{~A}$ single dose of $100 \mathrm{CFU}$ is sufficient to infect cattle ${ }^{47}$ while sheep have been been infected by a single oral dose of $10^{5} \mathrm{CFU}$. $^{48}$ These doses can be acquired by ingestion of as little as $0.1 \mathrm{~g}$ of manure containing $10^{6} \mathrm{CFU} / \mathrm{g} .{ }^{48}$ Shedding of the pathogen in cattle is intermittent, ${ }^{45,49}$ the duration of shedding by cattle is less than a month and shedding peaks occur during the months of summer. ${ }^{49,50}$ Weaning calves are reported to shed more bacteria than other age groups. ${ }^{50,51}$ These findings suggest that having negative results at a particular point in time does not indicate absence of STEC O157:H7. Moreover, the reported prevalence of STEC 0157:H7 may be lower or higher than the real situation depending on the composition of cattle, by age, in the study.

Accidental ingestion of STEC 0157:H7 following contact with infected animals or the contaminated environment has led to human infection. ${ }^{7,52,53}$ Contaminated food products such as beef, $4,5,20,22,25,33$ chevon, mutton, ${ }^{20,21,25}$ milk and chicken may lead to human infection. ${ }^{22,25}$ Marine environmental contamination has also posed a risk because of isolation of the pathogen from shellfish. ${ }^{23}$ Convenient foods under poor preparation or handling have also been reported to play a role in propagation of this pathogen. ${ }^{37}$ Moreover, inanimate objects such as soil, ${ }^{7}$ water, ${ }^{28,46}$ marine sediment ${ }^{23}$ and manure ${ }^{50}$ are a source of the pathogen. The risk is potentiated by the ability of the pathogen to survive harsh conditions, such as the low $\mathrm{pH}$ of dairy products, ${ }^{54,55}$ or in manure for more than four months. ${ }^{48}$ Generally, the risk factors for STEC 0157:H7 infections include contact with animals and their environment and poor personal hygiene, such as not washing hands after handling animals or prior to eating. ${ }^{7,52,53}$ These findings and reports call for hygiene observance after contact with animals, the suspected environment or during preparation of foods.

In Africa, evidence of STEC 0157:H7 transmission between humans, animals and environment is not clear. From the reports in this review, isolation of STEC 0157:H7 from humans was driven by the occurrence of disease syndromes, such as diarrhoea, while detection of the pathogen from animals, animal product and the environment was part of routine research work. There is no 
temporal relationship in isolation from these two ends. Under such a scenario, it is difficult to establish events and direction of transmission, as well as to quantify the risk of pathogen transfer between humans, livestock and the environment. There is a need to investigate the possible sources and to quantify risk factors every time STEC 0157:H7 is isolated from humans to ensure that prevention and control strategies are appropriate.

\section{Isolation and characterisation of STEC 0157:H7}

Like any other member of the family Enterobacteriaceae, Shiga toxin-producing Escherichia coli 0157:7 can be isolated on MacConkey agar, followed by conventional biochemical or serological tests to confirm that the isolates are E. coli. Isolation can also be done by use of sorbitol MacConkey agar whereby most STEC 0157:H7 are distinguished from other strains by their inability to ferment sorbitol. Direct inoculation of a sample on sorbitol MacConkey agar has been employed, but has been proven to be less sensitive compared to immunomagnetic separation. ${ }^{56,57}$ Some studies have employed both sorbitol MacConkey agar and immunomagnetic separation to maximise the chances of isolating the pathogen. ${ }^{32}$ STEC 0157:H7 strains should be distinguished from Non-O157:H7 strains, which also do not ferment sorbitol. ${ }^{18}$ Either of these $E$. coli isolation options can be accomplished by performing an agglutination test using antibodies against a somatic antigen for $\mathrm{O} 157: \mathrm{H7}$ and a flagella antigen for $\mathrm{H7}$. Polymerase chain reaction (PCR) for the detection of shiga toxin-producing genes in E. coli O157:H7 remains a gold standard detection method. ${ }^{57}$ Detection of the bacteria or toxins may take more than $24 \mathrm{~h} .{ }^{58}$ In some instances, DNA hybridisation has been performed to affirm additional virulence genes and phenotypic activities of shiga toxin-producing genes proven by Vero-cell cytotoxicity assay.

In the present review, sorbitol MacConkey agar was used in isolation of STEC 0157:H7 in 21 out of 24 reports from Africa. An immunomagnetic separation technique was employed in seven reports, in which it was used together with sorbitol MacConkey agar. After isolation, the characterisation of E. coli $0157: \mathrm{H} 7$ was done by polymerase chain reaction $(\mathrm{PCR})$ to detect the shiga toxin-producing genes (14 reports), 0157 antisera for detection of somatic antigen $\mathrm{O} 157$ (18 reports) and dot plot DNA hybridisation was used to confirm PCR results (2 reports). Serotyping of O157:H7 antigens was performed in four studies, while Vero-cell cytotoxicity assays were performed to test for cytopathic effects on Vero-cell monolayers in six studies that are included in this review (Table 1). The use of molecular methods (PCR) to detect shiga toxin-producing genes in only 14 out of 24 (58\%) studies in this review could have resulted in missed detection and underreporting of STEC in Africa. All these STEC 0157:H7 detection methods required more than $24 \mathrm{~h}$ to complete. Moreover, not many laboratories in Africa can afford these diagnostic procedures. There is a need to improve diagnostic facilities in Africa - even by starting with a few reference laboratories in each African country - which will enable quick and accurate detection of STEC 0157:H7 infection. This will help to avoid inappropriate management of cases, such as use of antimicrobials which are easily accessed in Africa and often without prescription, for any enteric illness including STEC O157:H7 infection.

Table 1: Sources and methods of STEC 0157 isolation and characterisation in African continent

\begin{tabular}{|c|c|c|c|}
\hline Country & Source & Isolation and characterisation method* & Author \\
\hline \multirow{2}{*}{ Central African Republic } & Human & PCR & Germani et al. 1997 \\
\hline & Cattle, fish, water, environment & SMAC, anti 0157 antisera and VCA & Tuyet et al. 2006 \\
\hline Cameroon & Human & SMAC, anti 0157 antisera, O:H serotyping and VCA & Cunin et al. 1999 \\
\hline \multirow[t]{2}{*}{ Tanzania } & Human & SMAC, IMS, anti 0157 antisera and PCR & Raji et al. 2008 \\
\hline & Cattle & $\begin{array}{l}\text { SMAC, anti } 0157 \text { antisera, PCR, DNA hybridization, O:H serotyping } \\
\text { and VCA }\end{array}$ & Lupindu et al. 2014 \\
\hline \multirow[t]{2}{*}{ Kenya } & Human & PCR, DNA hybridization, VCA & Sang et al. 1996 \\
\hline & Cattle, food (milk) & SMAC, anti 0157 antisera and PCR & Kang'ethe et al. 2007 \\
\hline \multirow[t]{2}{*}{ Ethiopia } & Beef, mutton and chevon & SMAC, O:H serotyping & Hiko et al. 2008 \\
\hline & Water, sheep, goats & IMS, SMAC, anti 0157 antisera and PCR & Mersha et al. 2010 \\
\hline Algeria & Cattle (carcass) & SMAC, anti 0157:H7 antisera, PCR, DNA hybridization & Chahel et al. 2006 \\
\hline \multirow[t]{3}{*}{ Morocco } & Food (Dairy and meat products) & IMS, SMAC, anti 0157 antisera and PCR & Benkerroum et al. 2004 \\
\hline & Raw meat products & IMS, SMAC, anti 0157 antisera and PCR & Beneduce et al. 2008 \\
\hline & Shellfish & SMAC, anti 0157 antisera and PCR & Bennani et al. 2011 \\
\hline Tunisia & Human & SMAC, anti 0157 antisera, PCR and VCA & Al-Gallas et al. 2006 \\
\hline Egypt & Beef, chicken, lamb and milk & SMAC and O:H serotyping & Abdul-Raouf et al. 1995 \\
\hline \multirow[t]{3}{*}{ Nigeria } & Human & SMAC, anti 0157 antisera. VCA & Olorunshola et al. 2000 \\
\hline & Cattle, food, sheep, goat, pig & SMAC and anti 0157 antisera & Ojo et al. 2010 \\
\hline & Human, water & SMAC, anti 0157 antisera & Chigor et al. 2010 \\
\hline \multirow[t]{2}{*}{ South Africa } & Human, vegetable & IMS, SMAC and PCR & Abong'o et al. 2008 \\
\hline & Food & IMS, SMAC and PCR & Abong'o and Momba 2009 \\
\hline Botswana & Food (meat) & IMS, SMAC and anti 0157 antisera & Magwira et al. 2004 \\
\hline Malawi & Maize porridge, vegetable, beans & SMAC, anti 0157 antisera & Taulo et al. 2008 \\
\hline Mozambique & Human & PCR & Mandomando et al. 2007 \\
\hline Zimbabwe & Human & SMAC & Gwavava et al. 2001 \\
\hline
\end{tabular}

*SMAC = sorbitol MacConkey agar, IMS = immunomagnetic separation, VCA = Vero-cell assay. 


\section{Pathogenicity of STEC 0157:H7 infection}

STEC 0157:H7 possesses different virulence factors that are important in pathogenicity. The major virulence factor is the shiga toxin. Two forms of the toxin, stx 1 and st 2 encoded by stx 1 and stx 2 genes are known $n^{59}$ and reported to be responsible for haemorrhagic uremic syndrome (HUS). ${ }^{60}$ The stx 1 is divided into three subtypes (stx1a, stx1c and stx1d) while seven subtypes form the st $\times 2$ group (st $\times 2 a$, st $\times 2 b$, st $\times 2 c, s t \times 2 d, s t \times 2 e, s t \times 2 f$ and stx2g). ${ }^{61}$ Of the two groups, subtypes of stx2 are associated with more severe HUS syndrome. ${ }^{62}$ Shiga toxins, which are protein molecules, bind to eukaryotic surface cells and inhibit protein synthesis with the death of host cells as a consequence..$^{63}$ Intimin is another virulence factor which is coded by attaching and effacing the eae gene. ${ }^{64}$ Intimin is reported to facilitate attachment of bacteria to intestinal epithelia during colonisation resulting into production of lesions and diarrhoea. ${ }^{59,65,66}$ This virulence factor is also possessed by enteropathogenic $E$. coli (EPEC) ${ }^{67}$ Enterohaemolysin is another virulence factor for STEC 0157:H7. This protein toxin damages cell membranes of erythrocytes and is used as a surrogate tool in detection of shiga toxin-producing E. coli. ${ }^{68-70}$ Although enterohaemolysin activity can easily be visualised on blood agar cultures, confirmation is usually achieved by PCR amplification of the ehxA gene. ${ }^{59,68}$ Some other E. coli strains such as O26, O103, 0111, 0118, 0128, 0121, $\mathrm{O} 45$ and $\mathrm{O} 145$ can produce disease syndromes and have been reported to be enterohaemolysin-positive and produce shiga toxins. ${ }^{68,70-72}$ The synergic effects of these virulence factors make STEC 0157:H7 a potential pathogen to humans. All virulence genes, namely stx 1, stx2, eae and ehxA genes, have been detected in humans, livestock, food products and the environment in eight different combinations as reported in 22 studies from Africa. ${ }^{8}$ The most dominant combination was st $1+s t \times 2$. Cattle are the most common source of STEC 0157:H7, as shown in Table 2. Therefore, it is important to consider the use of diagnostic approaches which target different genes so as to increase the sensitivity of STEC 0157:H7-related studies.

\section{Disease syndromes caused by STEC 0157:H7}

To date, STEC 0157:H7 has been reported to cause intestinal and extra-intestinal disease symptoms in humans. Disease symptoms may take different forms such as diarrhoea, ${ }^{17}$ haemorrhagic colitis ${ }^{13,19}$ or haemolytic uremic syndrome. ${ }^{13}$ Haemolytic uremic syndrome, which is characterised by thrombocytopenia,

Table 2: STEC 0157:H7 virulence factor combinations from studies in Africa

\begin{tabular}{|c|c|c|c|}
\hline $\begin{array}{l}\text { Gene } \\
\text { combination }\end{array}$ & Source & Reports & Countries \\
\hline stx1 & Cattle feces, milk & 2 & Kenya \\
\hline stx2 & $\begin{array}{l}\text { Cattle feces, human } \\
\text { stool }\end{array}$ & 2 & $\mathrm{CAR}^{*}$ and Kenya \\
\hline$s t x 1+e a e$ & Human stool & 1 & $\mathrm{CAR}^{*}$ \\
\hline$s t x 1+s t x 2$ & $\begin{array}{l}\text { Cattle feces, water, } \\
\text { fish, human stool, } \\
\text { milk, beef, goat, } \\
\text { sediment }\end{array}$ & 6 & $\begin{array}{l}\text { CAR, Ethiopia, } \\
\text { Egypt and Morocco }\end{array}$ \\
\hline$e a e+e h x A$ & Cattle feces, pig & 1 & South Africa \\
\hline$e a e+s t x 2+e h x A$ & $\begin{array}{l}\text { Cattle feces, cattle } \\
\text { carcass }\end{array}$ & 2 & $\begin{array}{l}\text { Tanzania and } \\
\text { Algeria }\end{array}$ \\
\hline$s t \times 1+s t \times 2+e a e$ & Human stool, beef & 2 & $\begin{array}{l}\text { Cameroon and } \\
\text { Morocco }\end{array}$ \\
\hline $\begin{array}{l}s t x 1+s t \times 2+e a e \\
+e h x A\end{array}$ & $\begin{array}{l}\text { Cattle feces, goat, } \\
\text { sheep, pig, human } \\
\text { stool }\end{array}$ & 2 & $\begin{array}{l}\text { Nigeria, South } \\
\text { Africa and Tunisia }\end{array}$ \\
\hline
\end{tabular}

haemolytic anaemia and nephropathy, may come as a complication of STEC 0157H7 infection following prolonged illness or sometimes disease management such as the use of antibiotics. $^{73}$ However, some humans do not show signs of disease despite infection and these are known as asymptomatic carriers..$^{24,74}$ Disease syndromes by STEC 0157:H7 in Africa have been reported to take the form of an epidemic ${ }^{13,16}$ whereby the 1992 outbreak in Swaziland and South Africa are reported to be the largest in Africa. ${ }^{75}$ However, sporadic forms of the disease have posed a threat to public health as well. ${ }^{19}$

\section{Treatment of STEC 0157:H7 infection}

Infections with shiga toxins-producing bacteria such as Shigella dysenteriae type I and STEC are controlled by the use of antibiotics and supportive therapies. ${ }^{13,76}$ However, in complicated forms of infection, like with HUS, antibiotics are not effective..$^{13,76}$ Administration of antibiotics to patients infected with STEC O157:H7 is reported to increase the release of shiga toxins and thus increasing the risk of developing HUS. ${ }^{13,73}$ This is thought to be due to the increased release of toxins following death of STEC. $^{73}$ The case is different, however, in S. dysenteriae type I infection where early antimicrobial therapy lowers the risk of developing HUS. ${ }^{76}$ Therefore, it is important to establish the etiology of an enteric disease before administration of antibiotics because it may worsen the prognosis in case of a STEC infection. This demand presents a challenge in developing countries where diagnostics do not match the requirements and antibiotics are haphazardly used. ${ }^{77,78}$

\section{Antimicrobial resistance in STEC 0157:H7}

Different studies in Africa have reported resistance of STEC O157:H7 to different antimicrobials. For instance, occurrence of multi-drug resistant STEC 0157:H7 isolated from humans, animals and the environment has been reported in Egypt, ${ }^{79}$ while isolation of multi-drug resistant STEC 0157:H7 from cattle in South Africa have also been reported. ${ }^{80}$ Similar results have been reported by Chigor et al. in Nigeria. Multi-drug resistance may seem of less importance since antimicrobials are not used to treat STEC 0157:H7 infection, but there may be a contribution towards selection for resistance genes.

\section{Control of STEC 0157:H7 infection}

Research on vaccination of reservoirs in an effort to reduce bacteria shedding has shown signs of success, ${ }^{81}$ but the practicality of this approach is questionable due to the use of transgenic tobacco plant cells. ${ }^{9}$ Some substances such as essential oils from Cinnamomum zeylanicum have shown bactericidal activities. ${ }^{82}$ But, the above efforts plus dietary manipulations are not promising strategies. Thus, hygienic management of animal and food products remain better options in control of STEC transmission. Moreover, we suggest structuring of an inter-sectoral cooperation between the veterinary (where the main reservoir, cattle, belong) and medical profession (where patients are cared for). A platform for exchange of information and strategies can help in controlling the emergence and spread of the pathogen.

\section{STEC 0157:H7 special prone group}

Shiga toxin-producing E. coli infect all sexes and ages, but many reported cases involve young and elderly people. ${ }^{19,35}$ However, the susceptibility spectrum is broadening such that, apart from the usual prone groups of the young and elderly, immunocompromised people form part of a group at risk. Cases of STEC 0157:H7 infections in people living with HIV/AIDS have been reported in Africa. ${ }^{32,36}$ This poses a big challenge because 
Africa has a large share in the global HIV/AIDS burden. Furthermore, complications of STEC 0157:H7 infections, e.g. HUS, are aggravated by the use of antibiotics in HIV/AIDS patients and are essential to combat other opportunistic microorganism infections. Subsequently, there becomes imbalance between the desire to alleviate the effects of opportunistic pathogens and shiga-toxins in HIV/AIDS patients due to contrasting outcomes of antimicrobial use. Reports of antibiotic use, such as ciprofloxacin, meropenem, fosfomycin, chloramphenicol, azithromycin and rifaximin, in treatment of STEC 0104:H4 infections without induction of shiga toxin release ${ }^{83,84}$ are promising. More research on these antibiotics is required to ascertain the possibility of their use to treat STEC 0157:H7 patients with HIV/AIDS.

\section{STEC non-0157:H7}

Although STEC 0157:H7 is the most commonly reported cause of human gastroenteritis, STEC non-O157:H7 pose an increasing risk in public health. When isolation procedures do not specifically target 0157:H7 strain, the proportion of STEC isolation skews towards non-0157:H7. In Africa most of the major worldwiderecognised non-O157 serotypes (0103, O111, 0145 and 026$)$ have been isolated from different parts of the continent. For instance, in Egypt STEC O26, 0114, 0125 and 0158 have been isolated from humans, cattle, sheep, chickens and water. ${ }^{85,86}$ In Tanzania, STEC 0113 has been isolated from cattle faeces. ${ }^{18}$ In South Africa, screening of STEC isolates from diarrhoeic human patients revealed isolation of STEC O4, O5, O21, O26, 084 and O111, in addition to $0157 .{ }^{72}$ In the same country, STEC O26 and 0145 have been isolated from pig faeces. ${ }^{87}$ These reports suggest that whenever STEC-related gastroenteritis is suspected, we should also consider other strains of STEC, not only 0157, because failure to isolate 0157:H7 may mislead the cause of illness. On the other hand, diagnosis of STEC-related gastroenteritis based on detection of shiga toxins could help in avoiding this discrimination.

The most recent and striking non-STEC 0157-related HUS outbreak in German in 2011 was caused by 0104:H4 strain. This strain had previously been isolated from diarrhoeic patients in Central African Republic in the mid-nineties. ${ }^{88}$

\section{Conclusion}

Isolation of STEC 0157:H7 from animals and food products reported from almost all over Africa suggests a high risk for human infection. Lack of proper laboratory facilities, especially in rural settings of Africa, interferes with definitive diagnoses and, hence, patients are treated tentatively. As such, antibiotic prescribed to patients with gastroenteritis can be fatal especially in case of STEC 0157:H7 infection. Additionally, difficulty in managing infection cases and time consuming diagnostic procedures call for preventive approaches rather than curative measures. Proper cattle and manure handling practices as well as public awareness on the epidemiology of the pathogen should be instituted. Vehicles of transmission, such as food products and water, should be decontaminated so as to prevent health implications due to STEC 0157:H7 infection.

\section{Conflict of interest - The author declares no conflict of interest.}

Acknowledgement - This review was done during execution of the project 'Opportunities and challenges in peri-urban livestock farming in Tanzania' (P6-08-Tan). The author wishes to thank the Ministry of Foreign Affairs of Denmark and the Danish International Development Agency (DANIDA) for financial support to the project.

\section{References}

1. Nataro JP, Kaper JB. Diarrheagenic Escherichia coli. Clin Microbiol Rev. 1998;11(1): 142-201.

2. Riley LW, Remis RS, Helgerson SD, et al. Hemorrhagic colitis associated with a rare Escherichia coli serotype. N Eng J Med. 1983;308(12): 681. https://doi.org/10.1056/NEJM198303243081203

3. Wells JG, Davis BR, Wachsmuth IK, et al. Laboratory investigation of hemorrhagic colitis outbreaks associated with a rare Escherichia coli serotype. J Clin Microbiol. 1983;18(3): 512-20.

4. Beneduce L, Spano G, Nabi AQ, et al. Occurrence and characterization of Escherichia coli 0157 and other serotypes in raw meat products in Morocco. J Food Protect. 2008;71(10): 2082-6. https://doi.org/10.4315/0362-028X-71.10.2082

5. Chahed A, China B, Mainil J, et al. Prevalence of enterohaemorrhagic Escherichia coli from serotype $\mathrm{O} 157$ and other attaching and effacing Escherichia coli on bovine carcasses in Algeria. J Appl Microbiol. 2006 Aug;101(2): 361-8. https://doi.org/10.1111/jam.2006.101.issue-2

6. Kang'ethe EK, Onono JO, McDermott B, et al. Isolation of E. coli 0157:H7 from milk and cattle faeces from urban dairy farming and non dairy farming neighbour households in Dagoretti Division, Nairobi, Kenya: prevalence and risk factors. East Afr Med J 2007 Nov;84(11 Suppl): S65-75.

7. Howie H, Mukerjee A, Cowden J, et al. Investigation of an outbreak of Escherichia coli 0157 infection caused by environmental exposure at a scout camp. Epidemiol Infect. 2003;131(3): 1063-9. https://doi.org/10.1017/S0950268803001250

8. Müller $\mathrm{EE}$, Ehlers MM. Grabow WOK. The occurrence of E. coli 0157: H7 in South African water sources intended for direct and indirect human consumption. Water Res. 2001;35(13): 3085-8. https://doi.org/10.1016/S0043-1354(00)00597-2

9. Caprioli $A$, Morabito $S$, Brugère $H$, et al. Enterohaemorrhagic Escherichia coli: emerging issues on virulence and modes of transmission. Veterinary research. 2005;36(3): 289-311. https://doi.org/10.1051/vetres:2005002

10. Hancock DD, Besser TE, Kinsel ML, et al. The prevalence of Escherichia coli 0157.H7 in dairy and beef cattle in Washington State. Epidemiol Infect. 1994 Oct;113(2): 199-207. https://doi.org/10.1017/S0950268800051633

11. Strachan NJC, Fenlon DR, Ogden ID. Modelling the vector pathway and infection of humans in an environmental outbreak of Escherichia coli 0157. FEMS Microbiol Lett. 2001;203(1): 69-73. https://doi.org/10.1111/fml.2001.203.issue-1

12. Avery LM, Killham K, Jones DL. Survival of E. coli O157:H7 in organic wastes destined for land application. J Appl Microbiol. 2005;98(4): 814-22. https://doi.org/10.1111/jam.2005.98.issue-4

13. Germani Y, Soro B, Vohito M, et al. Enterohaemorrhagic Escherichia coli in Central African Republic. The Lancet. 1997;349: 1670. https://doi.org/10.1016/S0140-6736(05)62636-0

14. Majowicz SE, Scallan E, Jones-Bitton A, et al. Global incidence of human Shiga toxin-producing Escherichia coli infections and deaths: a systematic review and knowledge synthesis. Foodborne Pathog Dis. 2014;11(6): 447-55. https://doi.org/10.1089/fpd.2013.1704

15. Browning NG, Botha JR, Sacho $H$, et al. Escherichia coli O157: H7 haemorrhagic colitis. Report of the first South African case. South African J Surg Suid-Afrikaanse tydskrif vir chirurgie. 1990;28(1): 28.

16. Cunin P, Tedjouka E, Germani Y, et al. An epidemic of bloody diarrhea: Escherichia coli O157 emerging in Cameroon? Emerg Infect Dis. 1999 Mar-Apr;5(2):285-90. https://doi.org/10.3201/eid0502.990217

17. Raji MA, Minga UM, Machang'u RS. Prevalence and characterization of verotocytoxin producing Escherichia coli 0157 from diarrhoea patients in Morogoro, Tanzania. Tanzan J Health Res. 2008 Jul;10(3): 151-8.

18. Lupindu AM, Olsen JE, NgowiHA, et al.Occurrenceand characterization of Shiga Toxin-producing Escherichia coli 0157:H7 and other nonsorbitol-fermenting $E$. coli in cattle and humans in urban areas of Morogoro, Tanzania. Vector-Borne Zoonotic Dis. 2014;14(7): 503-10. https://doi.org/10.1089/vbz.2013.1502

19. Sang WK, Saidi SM, Yamamoto $H$, et al. Haemorrhagic colitis due to Escherichia coliO157:H7 in Kenya. JTrop Pediatr. 1996 Apr;42(2): 118-9. https://doi.org/10.1093/tropej/42.2.118

20. Hiko A, Asrat D, Zewde G. Occurrence of Escherichia coli 0157:H7 in retail raw meat products in Ethiopia. J Infect Dev Ctries. 2008;2(5): 389-93. 
21. Mersha G, Asrat D, Zewde BM, et al. Occurrence of Escherichia coli 0157:H7 in faeces, skin and carcasses from sheep and goats in Ethiopia. Lett Appl Microbiol. 2010 Jan;50(1):71-6. https://doi.org/10.1111/lam.2009.50.issue-1

22. Benkerroum N, Bouhlal Y, El Attar A, et al. Occurrence of shiga toxin-producing Escherichia coli 0157 in selected dairy and meat products marketed in the city of Rabat, Morocco. J Food Protect. 2004;67(6):1234-7. https://doi.org/10.4315/0362-028X-67.6.1234

23. Bennani $M$, Badri S, Baibai T, et al. First detection of Shiga toxinproducing Escherichia coli in shellfish and coastal environments of Morocco. Appl Biochem Biotechnol. 2011 Sep;165(1):290-9. https://doi.org/10.1007/s12010-011-9251-x

24. Al-Gallas N, Bahri O, Aissa RB. Prevalence of shiga toxin-producing Escherichia coli in a diarrheagenic Tunisian population, and the report of isolating STEC 0157: H7 in Tunis. Curr Microbiol. 2006;53(6): 48390. https://doi.org/10.1007/s00284-006-0184-5

25. Abdul-Raouf UM, Ammar MS, Beuchat LR. Isolation of Escherichia coli O157:H7 from some Egyptian foods. Int J Food Microbiol. 1996 Apr;29(2-3):423-6. https://doi.org/10.1016/0168-1605(95)00076-3

26. Olorunshola ID, Smith SI, Coker AO. Prevalence of EHEC 0157: H7 in patients with diarrhoea in Lagos, Nigeria. Apmis. 2000;108(11): 7613. https://doi.org/10.1034/j.1600-0463.2000.d01-26.x

27. Ojo OE, Ajuwape ATP, Otesile EB, et al. Potentially zoonotic shiga toxin-producing Escherichia coli serogroups in the faeces and meat of food-producing animals in Ibadan, Nigeria. Int J Food Microbiol. 2010;142(1-2):214-21. https://doi.org/10.1016/j. ijfoodmicro.2010.06.030

28. Chigor VN, Umoh VJ, Smith SI, et al. Multidrug resistance and plasmid patterns of Escherichia coli 0157 and other E. coli isolated from diarrhoeal stools and surface waters from some selected sources in Zaria, Nigeria. Int J Environ Res Public Health. 2010;7(10):3831-41. https://doi.org/10.3390/ijerph7103831

29. Addo KK, Mensah Gl, Aning KG, et al. Microbiological quality and antibioticresiduesininformallymarketedrawcowmilkwithinthecoastal savannah zone of Ghana. Trop Med Int Health. 2011 Feb;16(2): 227-32. https://doi.org/10.1111/tmi.2011.16.issue-2

30. Abong'o BO, Momba MNB. Prevalence and potential link between $E$. coli O157: $\mathrm{H} 7$ isolated from drinking water, meat and vegetables and stools of diarrhoeic confirmed and non-confirmed HIV/AIDS patients in the Amathole District - South Africa. J Appl Microbiol. 2008;105(2): 424-31. https://doi.org/10.1111/jam.2008.105.issue-2

31. Abong'o BO, Momba MNB. Prevalence and characterization of scherichia coli 0157: $\mathrm{H} 7$ isolates from meat and meat products sold in Amathole District, Eastern Cape Province of South Africa. Food Microbiol. 2009;26(2):173-6. https://doi.org/10.1016/j. fm.2008.10.001

32. Abong'o BO, Momba MNB, Mwambakane JN, et al. Prevalence of Escherichia coli 0157:H7 among diarrhoeic HIV/AIDS patients in Eastern Cape Province-South Africa. Pakistan J Bilogical Sci. 2008;11(8): 1066-75.

33. Magwira CA, Gashe BA, Collison EK. Prevalence and antibiotic resistance profiles of Escherichia coli 0157:H7 in beef products from retail outlets in Gaborone, Botswana. J Food Prot. 2005 Feb;68(2): 403-6. https://doi.org/10.4315/0362-028X-68.2.403

34. Taulo S, Wetlesen A, Abrahamsen R, et al. Microbiological hazard identification and exposure assessment of food prepared and served in rural households of Lungwena, Malawi. Int J Food Microbiol. $2008 \mathrm{Jul}$ 15;125(2): 111-6. https://doi.org/10.1016/j.ijfoodmicro.2008.02.025

35. Mandomando IM, Macete EV, Ruiz J, et al. Etiology of diarrhea in children younger than 5 years of age admitted in a rural hospital of southern Mozambique. Am J Trop Med Hyg. 2007;76(3):522-7.

36. Gwavava C, Chihota VN, Gangaidzo IT, et al. Dysentery in patients infected with human immunodeficiency virus in Zimbabwe: an emerging role for Schistosoma mansoni and Escherichia coli 0157? Ann Trop Med Parasitol. 2001;95(5):509-13. https://doi.org/10.1080/ 00034983.2001 .11813663

37. Tuttle J, Gomez T, Doyle MP, et al. Lessons from a large outbreak of Escherichia coli O157: H7 infections: insights into the infectious dose and method of widespread contamination of hamburger patties. Epidemiol Infect. 1999;122(2):185-92. https://doi.org/10.1017/ S0950268898001976
38. Ateba CN, Bezuidenhout CC. Characterisation of Escherichia coli 0157 strains from humans, cattle and pigs in the North-West Province, South Africa. Int J Food Microbiol. 2008;128(2):181-8. https://doi.org/10.1016/j.ijfoodmicro.2008.08.011

39. Ateba CN, Mbewe M. Detection of Escherichia coli O157: H7 virulence genes in isolates from beef, pork, water, human and animal species in the northwest province, South Africa: public health implications. Res Microbiol. 2011;162(3):240-8. https://doi.org/10.1016/j. resmic.2010.11.008

40. Cobbaut K, Houf K, Buvens G, et al. Occurrence of non-sorbitol fermenting, verocytotoxin-lacking Escherichia coli 0157 on cattle farms. Vet Microbiol. 2009 Jul 2;138(1-2):174-8. https://doi. org/10.1016/j.vetmic.2009.02.008

41. Heuvelink AE, Valkenburgh SM, Tilburg J, et al. Public farms: hygiene and zoonotic agents. Epidemiol Infect. 2007;135(7):1174-83.

42. Kaddu-Mulindwa DH, Aisu T, Gleier K, et al. Occurrence of Shiga toxin-producing Escherichia coli in fecal samples from children with diarrhea and from healthy zebu cattle in Uganda. Int J Food Microbiol. 2001;66(1):95-101. https://doi.org/10.1016/S0168-1605(00)00493-1

43. Dorn CR, Angrick EJ. Serotype O157:H7 Escherichia coli from bovine and meat sources. J Clin Microbiol. 1991 Jun;29(6):1225-31.

44. El-SayedA,AhmedS,AwadW.Docamels (Camelusdromedarius) playan epidemiological role in the spread of Shiga Toxin producing Escherichia coli (STEC) infection? Trop Anim Health Prod. 2008;40(6):469-73. https://doi.org/10.1007/s11250-007-9122-1

45. Shere JA, Bartlett KJ, Kaspar CW. Longitudinal study of Escherichia coli O157: H7 dissemination on four dairy farms in Wisconsin. Appl Environ Microbiol. 1998;64(4):1390-9.

46. Tuyet DT, Yassibanda S, Nguyen Thi PL, et al. Enteropathogenic Escherichia coli 0157 in Bangui and N'Goila, Central African Republic: a brief report. Am J Trop Med Hyg. 2006 Sep;75(3):513-5.

47. Hancock DD, Besser TE, Rice DH, editors. Ecology of Escherichia coli 0157: H7 in cattle and impact of management practices. In: Kaper J B, O'Brien A D, editors, Escherichia coli O157:H7 and other Shiga toxinproducing E coli strains. Washington, DC: ASM Press; 1997. pp. 85-91.

48. Kudva IT, Blanch K, Hovde CJ. Analysis of Escherichia coli O157:H7 survival in ovine or bovine manure and manure slurry. Appl Environ Microbiol. 1998 Sep;64(9):3166-74.

49. Besser TE, Hancock DD, Pritchett LC, et al. Duration of detection of fecal excretion of Escherichia coli 0157:H7 in cattle. J Infect Dis. 1997;175: 726-9. https://doi.org/10.1093/infdis/175.3.726

50. Hutchison ML, Walters LD, Avery SM, et al. Analyses of livestock production, waste storage, and pathogen levels and prevalences in farm manures. Appl Environ Microbiol. 2005;71(3):1231-6. https:// doi.org/10.1128/AEM.71.3.1231-1236.2005

51. LaegreidWW, Elder RO, Keen JE. Prevalence of Escherichia coliO157: H7 in range beef calves at weaning. Epidemiol Infect. 1999;123(2):291-8. https://doi.org/10.1017/S0950268899002757

52. Crump JA, Sulka AC, Langer AJ, et al. An outbreak of Escherichia coli 0157: H7 infections among visitors to a dairy farm. N Eng J Med. 2002;347(8):555-60. https://doi.org/10.1056/NEJMoa020524

53. Smith KE, Stenzel SA, Bender JB, et al. Outbreaks of enteric infections caused by multiple pathogens associated with calves at a farm day camp. Pediatr Infect Dis J. 2004;23(12):1098-104.

54. Dlamini BC, Buys EM. Adaptation of Escherichia coli 0157: H7 to acid in traditional and commercial goat milk amasi. Food Microbiol. 2009;26(1):58-64. https://doi.org/10.1016/j.fm.2008.07.007

55. Tsegaye M, Ashenafi M. Fate of Escherichia coli O157:H7 during the processing and storage of Ergo and Ayib, traditional Ethiopian dairy products. Int J Food Microbiol. 2005 Aug 15;103(1):11-21. https://doi.org/10.1016/j.ijfoodmicro.2004.12.006

56. Chapman PA, Siddons CA. A comparison of immunomagnetic separation and direct culture for the isolation of verocytotoxinproducing Escherichia coli 0157 from cases of bloody diarrhoea, non-bloody diarrhoea and asymptomatic contacts. J Med Microbiol. 1996;44(4):267-71. https://doi.org/10.1099/00222615-44-4-267

57. Cubbon MD, Coia JE, Hanson MF, et al. A comparison of immunomagnetic separation, direct culture and polymerase chain reaction for the detection of verocytotoxin-producing Escherichia coli 0157 in human faeces. J Med Microbiol. 1996;44(3):219-22. https://doi.org/10.1099/00222615-44-3-219 
58. Gould LH. Update: recommendations for diagnosis of shiga toxin-producing Escherichia coli infections by clinical laboratories. Clin Microbiol Newslett. 2012;34(10):75-83. https://doi.org/10.1016/j.clinmicnews.2012.04.004

59. Gallien P. Detection and subtyping of Shiga toxin-producing Escherichia coli (STEC). Methods Mol Biol. 2003;216: 163-84.

60. Paton JC, Paton AW. Pathogenesis and diagnosis of Shiga toxinproducing Escherichia coli infections. Clin Microbiol Rev. 1998;11(3): 450-79.

61. Scheutz F, Teel LD, Beutin L, et al. Multicenter evaluation of a sequence-based protocol for subtyping Shiga toxins and standardizing Stx nomenclature. J Clin Microbiol. 2012;50(9):2951-63. https://doi.org/10.1128/JCM.00860-12

62. Persson S, Olsen KE, Ethelberg $S$, et al. Subtyping method for Escherichia coli Shiga toxin (verocytotoxin) 2 variants and correlations to clinical manifestations. J Clin Microbiol. 2007;45(6): 2020-4. https://doi.org/10.1128/JCM.02591-06

63. Sandvig K. Shiga toxins. Toxicon. 2001;39(11):1629-35. https://doi.org/10.1016/S0041-0101(01)00150-7

64. Jerse $A E, Y u ~ J$, Tall $B D$, et al. A genetic locus of enteropathogenic Escherichia coli necessary for the production of attaching and effacing lesions on tissue culture cells. Proc Natl Acad Sci U S A. 1990 Oct;87(20): 7839-43. https://doi.org/10.1073/pnas.87.20.7839

65. McDaniel TK, Jarvis KG, Donnenberg MS, et al. A genetic locus of enterocyte effacement conserved among diverse enterobacterial pathogens. Proc Natl Acad Sci U S A. 1995 Feb 28;92(5):1664-8. https://doi.org/10.1073/pnas.92.5.1664

66. Moon HW, Whipp SC, Argenzio RA, et al. Attaching and effacing activities of rabbit and human enteropathogenic Escherichia coli in pig and rabbit intestines. Infect Immun. 1983 Sep;41(3): 1340-51.

67. China B, Goffaux F, Pirson V, et al. Comparison of eae, tir, espA and espB genes of bovine and human attaching and effacing Escherichia coli by multiplex polymerase chain reaction. FEMS Microbiol Lett. 1999 Sep 1;178(1):177-82. https://doi.org/10.1111/fml.1999.178. issue-1

68. El Sayed Zaki M, El-Adrosy H. Diagnosis of Shiga toxin producing Escherichia coli infection, contribution of genetic amplification technique. Microbes Infect. 2007 Feb;9(2):200-3. https://doi. org/10.1016/j.micinf.2006.11.005

69. Jürgens D, Özel M, Takaisi-Kikuni NB. Production and characterization of Escherichia coli enterohemolysin and its effects on the structure of erythrocyte membranes. Cell Biol Int. 2002;26(2):175-86. https://doi.org/10.1006/cbir.2001.0831

70. Schmidt H, Beutin L, Karch H. Molecular analysis of the plasmidencoded hemolysin of Escherichia coli O157: H7 strain EDL 933. Infect Immun. 1995;63(3): 1055-61.

71. Gyles C, Johnson R, Gao A, et al. Association of Enterohemorrhagic Escherichia coliHemolysin with serotypes of shiga-like-toxinproducing Escherichia coli of human and Bovine origins. Appl Environ Microbiol. 1998 Nov 1;64(11): 4134-41.

72. Smith AM, Tau NP, Sooka A, et al. Surveillance for enterohaemorrhagic Escherichia coli associated with human diarrhoea in South Africa, 2006-2009. J Med Microbiol. 2011;60(5):681-3. https://doi. org/10.1099/jmm.0.022947-0

73. Wong CS, Jelacic S, Habeeb RL, et al. The risk of the hemolyticuremic syndrome after antibiotic treatment of Escherichia coli 0157:H7 infections. N Engl J Med. 2000 Jun 29;342(26):1930-6. https://doi.org/10.1056/NEJM200006293422601

74. Silvestro L, Caputo M, Blancato $S$, et al. Asymptomatic carriage of verocytotoxin-producing Escherichia coli 0157 in farm workers in Northern Italy. Epidemiol Infect. 2004 Oct;132(5):915-9. https://doi.org/10.1017/S0950268804002390
75. EfflerE,IsaäcsonM,ArntzenL,etal.Factorscontributingtotheemergence of Escherichia coli O157 in Africa. Emerging Infect Dis. 2001;7(5):812. https://doi.org/10.3201/eid0705.017507

76. Bennish ML, Khan WA, Begum M, et al. Low risk of hemolytic uremic syndrome after early effective antimicrobial therapy for Shigella dysenteriae type 1 infection in Bangladesh. Clin Infect Dis. 2006;42(3): 356-62. https://doi.org/10.1086/499236

77. Hounsa A, Kouadio L, De Mol P. Self-medication with antibiotics obtained from private pharmacies in Abidjan, Ivory Coast]. Médecine et maladies infectieuses. 2010;40(6):333. https://doi.org/10.1016/j medmal.2009.10.002

78. Vento S, Cainelli F. The need for new antibiotics. The Lancet 2010;375(9715):637. https://doi.org/10.1016/S0140-6736(10)60264-4

79. EL-Alfy SM, Ahmed SF, Selim SA, et al. Prevalence and characterization of Shiga toxin 0157 and non-0157 enterohemorrhagic Escherichia coli isolated from different sources in Ismailia, Egypt. Afr J Microbiol Res. 2013;7(21):2637-45.

80. Iweriebor BC, Iwu CJ, Obi LC, et al. Multiple antibiotic resistances among Shiga toxin producing Escherichia coli 0157 in feces of dairy cattle farms in Eastern Cape of South Africa. BMC Microbiol. 2015;15(1):213 https://doi.org/10.1186/s12866-015-0553-y

81. Potter AA, Klashinsky S, Li Y, et al. Decreased shedding of Escherichia coli 0157: $\mathrm{H} 7$ by cattle following vaccination with type III secreted proteins. Vaccine. 2004;22(3):362-9. https://doi.org/10.1016/j. vaccine.2003.08.007

82. Senhaji O, Faid M, Kalalou I. Inactivation of Escherichia coli 0157:H7 by essential oil from Cinnamomum zeylanicum. Braz J Infect Dis. 2007 Apr;11(2):234-6. https://doi.org/10.1590/S1413 86702007000200013

83. Bielaszewska M, Idelevich EA, Zhang W, et al. Effects of antibiotics on Shiga toxin 2 production and bacteriophage induction by epidemic Escherichia coli 0104: H4 strain. Antimicrob Agents Chemother. 2012;56(6):3277-82. https://doi.org/10.1128/AAC.06315-11

84. Corogeanu D, Willmes $R$, Wolke $M$, et al. Therapeutic concentrations of antibiotics inhibit Shiga toxin release from enterohemorrhagic E. coli O104: H4 from the 2011 German outbreak. BMC Microbiol. 2012;12(1):160. https://doi.org/10.1186/1471-2180-12-160

85. Selim SA, Ahmed SF, Aziz MHA, et al. Prevalence and characterization of Shiga-toxin 0157: H7 and non-O157: H7 enterohemorrhagic Escherichia coli isolated from different sources. Biotechnol Biotechnol Equip. 2013;27(3):3834-42. https://doi.org/10.5504/BBEQ.2013.0031

86. EL-Alfy SM, Ahmed SF, Selim SA, et al. Prevalence and characterization of Shiga toxin 0157 and non-O157 enterohemorrhagic Escherichia coli isolated from different sources in Ismailia, Egypt. Afr J Microbiol Res. 2013;7(21):2637-45.

87. Iwu CJ, Iweriebor BC, Obi LC, et al. Occurrence of non-O157 Shiga toxin-producing Escherichia coli in two commercial swine farms in the Eastern Cape Province, South Africa. Comp Immunol Microbiol Infect Dis. 2016;44:48-53. https://doi.org/10.1016/j.cimid.2015.12.004

88. Rasko DA, Webster DR, Sahl JW, et al. Origins of the $E$. coli strain causing an outbreak of hemolytic-uremic syndrome in Germany. N Engl J Med. 2011;365(8):709-17. https://doi.org/10.1056/NEJMoa1106920

Received: 17-09-2016 Accepted: 04-09-2017 